\title{
The Effectiveness of Snail Shell as Adsorbent For The Treatment of Waste Water From Beverage Industries Using $\mathrm{H}_{3} \mathrm{Po}_{4} \mathrm{As}$ Activating Agent
}

\author{
Udeozor S. O And * Evbuomwan B. O \\ Faculty of Process and Energy System Engineering. Department of Chemical Engineering \\ University of Port Harcourt, Port Harcourt, Nigeria.
}

\begin{abstract}
The effectiveness of Snail Shell as adsorbent for the treatment of wastewater from beverage industries, using Phosphoric acid $\left(\mathrm{H}_{3} \mathrm{PO}_{4}\right)$ as activating agent has been investigated. The snail shells were pyrolysed at $500^{\circ} \mathrm{C}$ and partitioned into two parts; one part as sample $\mathrm{A}$ and the other further treated with the activating agent as sample B. The samples were characterized for some important properties such as porosity, surface area, organic content, moisture content, and $\mathrm{pH}$; and sample B was used in all further experimental works. Wastewater from beverage industry was treated with the activated snail shell sample B, with a view to determining the extent of treatment with time. Some of the important wastewater parameters analyzed include: Biological oxygen Demand (BOD); Chemical Oxygen Demand (COD); Turbidity; Dissolved oxygen (DO); and Phosphate. The results obtained from the characterization of the snail shell adsorbent samples are: for sample A (Porosity, 48\%; Surface area, 2567.32 $\mathrm{m}^{2}$; Organic content, 12.5\%; Moisture content, $0.32 \%$; pH, 8.76); and for sample B (Porosity 72\%; Surface area, 2987.69 $\mathrm{m}^{2}$; Organic content, 7.3\%; Moisture content, 0.27\%; pH, 7.04). Also, the results of some of the physicochemical parameters of the waste water before and after treatment respectively, at a maximum time of $40 \mathrm{mins}$ are: $48 \mathrm{mg} / \mathrm{l}$ and $16 \mathrm{mg} / \mathrm{l}$ for BOD, $146 \mathrm{mg} / \mathrm{l}$ and $37 \mathrm{mg} / \mathrm{l}$ for COD, 41FAU and 1 FAU for turbidity, $1.8 \mathrm{mg} / \mathrm{l}$ and $4.98 \mathrm{mg} / \mathrm{l}$ for dissolved oxygen, $0.066 \mathrm{mg} / \mathrm{l}$ and $0.0001 \mathrm{mg} / \mathrm{l}$ for phosphate. In conclusion, this study has shown that activated carbon produced from snail shells can compete favorably with the conventional activated carbons in treating wastewater from beverage industry, using $\mathrm{H}_{3} \mathrm{PO}_{4}$ as an effective activating agent.
\end{abstract}

Key words: Snail shell, Activating agent, Characterization, Wastewater and Beverage

\section{INTRODUCTION}

Water is one of the most precious natural resources that exist in our planet, comprising over two third of the earth surface, that is why its pollution by both organic and inorganic chemicals is a serious environmental concern. Increasing population leading to increasing water use has already created pollution problems in many locations [1].

Food and beverage industries are major sources of industrial wastewater, and the wastewater generated from their operations has distinctive characteristics that set it apart from common municipal wastewater managed by public or private wastewater treatment plants throughout the world: it is biodegradable and nontoxic, with the exception of some toxic cleaning products, but has high concentration of Biochemical Oxygen Demand (BOD), and suspended solids. The constituents of these wastewater are often complex to predict due to the differences in $\mathrm{BOD}$ and $\mathrm{pH}$ in effluents from vegetable, fruit, and meat products and due to the seasonal nature of food processing.

Adsorption process is one of the most available and extensively used technologies to remove organic contaminants in wastewater treatment. Activated carbon is the most conventional adsorbent [2], particularly and commonly used owing to their large adsorption capacity, fast adsorption kinetics, relative ease of regeneration. Most of the commercial activated carbons are either coal based [3], [4] or petroleum pitch based [5] which are prone to exhaustion and their global distribution is non-uniform. As the applications of activated carbon are immense, the gap between demand and supply is ever widening. This may in due course result in scarcity of the material in addition to becoming expensive. This situation necessitates the need for the exploration of new sources of carbon materials with desired physiochemical properties namely, high specific surface area, micro- or meso porosity or both, depending on the end application, surface functionality, thermal stability, carbon purity, adsorptive capacity and chemical composition [6].

The use of snail shell has been found efficient as an absorbent, especially in the removal of heavy metals like lead, based on its adsorption capacity, available surface area, distribution ratio and percentage sorption [7]. The activation of these low cost precursors are done physically or chemically using various kinds of activating agents, depending on the end use of the adsorbent. Moreover, the chemical activation has some 
important advantages to that of the physical activation such as lower carbonization temperature and shorter time of activation.

The test for physico-chemical parameters such as Biochemical Oxygen Demand (BOD), Chemical Oxygen Demand (COD), Total Suspended Solid (TSS), and TOC (Total Organic Carbon) etc, common to all types of wastewater are used to measure and determine the organic content of wastewater, although these parameters as such do not show any chemical identity of organic matter [1]. This paper seek to investigate the effectiveness of treating beverage industry wastewater with activated carbon prepared from snail shell using phosphoric acid $\left(\mathrm{H}_{3} \mathrm{PO}_{4}\right)$ as activating agent.

\subsection{Preparation of sample}

\section{MATERIALS AND METHODS}

Nigeria.

Snail shells used were obtained from the waste of two major eateries located in Choba, Port Harcourt,

Granular activated carbon was prepared following the development of the procedures of [7] and [8]

- Snail shells from refuse dump were first collected and washed properly, in and out to remove dirt.

- The washed shells were dried first in open air and intense sunlight for about $2 \mathrm{hrs}$ and then put in an oven for another $2 \mathrm{hrs}$ at a temperature of $110^{\circ} \mathrm{C}$.

- The dried shells were made to undergo pyrolysis in a muffle furnance at $500^{\circ} \mathrm{C}$ as the carbonation temperature, using a carbonation time of $1 \mathrm{hr}$;

- The carbonized shells were then crushed and sieved to obtain sizes smaller than $600 \mu \mathrm{m}$. This product was then shared into two parts; while one part was characterized without chemical activation, the other was made to undergo chemical activation.

- Chemical activation was carried out on the crushed shells using $\mathrm{H}_{3} \mathrm{PO}_{4}$ as the activating agent with an impregnation ratio (i.e weight ratio of the activator to the precursor) of $3: 1$.

- During chemical activation, the sample was left to stay in an oven for a period of $20 \mathrm{hrs}$ as activating time at a temperature of $110^{\circ} \mathrm{C}$.

- Afterwards, the sample was rinsed using $500 \mathrm{ml}$ of a $1.2 \mathrm{M} \mathrm{HCl}$ and $500 \mathrm{ml}$ of distilled water and was decanted out.

\subsection{Characterization}

This involved the proximate and ultimate analysis of the activated carbon samples produced. The idea was to make comparison between the two samples: Sample A- is that which was not chemically treated with an activating agent. Sample B- is that which was chemically activated with activating agent, $\mathrm{H}_{3} \mathrm{PO}_{4}$. The analysis involved the determination of some very essential parameters of the produced samples.

\subsection{Analysis of wastewater}

The wastewater was analyzed before and after treatment with the chemically activated sample as described in the standard methods for wastewater and effluent analysis [9], and also the standard methods for the examination of water and wastewater [10]. These analyses involve the changes in the physiochemical parameters of the five(5) different samples of the wastewater i.e Raw wastewater sample 1, and the remaining four treated water samples; $10 \mathrm{mins}$ contact-time sample 2, 20mins contact-time sample 3, 30mins contact-time sample 4 and finally $40 \mathrm{mins}$ contact-time sample 5.

\section{RESULTS AND DISCUSSION}

The analysis of the results obtained are presented below:

TABLE 1: Properties of the Activated Carbon Samples, A and B

\begin{tabular}{|l|l|l|}
\hline Components & Non- $\mathbf{H}_{\mathbf{3}} \mathbf{P O}_{\mathbf{4}}$ activated, $\mathbf{A}$ & $\mathbf{H}_{\mathbf{3}} \mathbf{P O}_{\mathbf{4}}$ activated, B \\
\hline $\begin{array}{l}\text { Surface area }\left(\mathrm{m}^{2}\right) \\
\text { Porosity (\%) }\end{array}$ & 2567.32 & 2987.69 \\
$\begin{array}{l}\text { Organic /ash } \\
\text { content (\%) }\end{array}$ & 48 & 72 \\
$\begin{array}{l}\text { Moisture } \\
\text { content (\%) }\end{array}$ & 12.5 & 7.3 \\
pH $(-)$ & 0.32 & 0.27 \\
\hline
\end{tabular}


TABLE 2: Particle Size Distribution of Sample A

\begin{tabular}{|llllcc|}
\hline $\begin{array}{l}\text { Sieve Diam. } \\
(\mathbf{m m})\end{array}$ & $\begin{array}{l}\text { Limits of the } \\
\text { particle sizes } \\
(\mathbf{m m})\end{array}$ & $\begin{array}{l}\text { Mass of particles } \\
\text { retained(g) }\end{array}$ & $\begin{array}{l}\text { \% } \\
\text { Retained }\end{array}$ & $\begin{array}{l}\text { \% } \\
\text { Cumulative } \\
\text { Retained }\end{array}$ & $\begin{array}{c}\text { \% } \\
\text { Cumulative } \\
\text { passing }\end{array}$ \\
2 & $2.00-4.00$ & 0.2 & 0.1 & 0.1 & 99.9 \\
1 & $1.00-2.00$ & 0.4 & 0.2 & 0.3 & 99.7 \\
0.425 & $0.425-1.00$ & 52.4 & 29.7 & 30.0 & 70.0 \\
0.250 & $0.250-0.425$ & 38.1 & 21.6 & 51.6 & 48.4 \\
0.150 & $0.150-0.250$ & 28.7 & 16.3 & 67.9 & 32.1 \\
0.063 & $0.063-0.150$ & 44.3 & 25.0 & 92.9 & 7.1 \\
PAN & $0.000-0.063$ & 12.2 & - & - & - \\
\hline
\end{tabular}

TABLE 3: Particle Size Distribution of Sample B

\begin{tabular}{|lllccc|}
\hline $\begin{array}{l}\text { Sieve Diam. } \\
(\mathbf{m m})\end{array}$ & $\begin{array}{l}\text { Limits of the } \\
\text { particle sizes } \\
(\mathbf{m m})\end{array}$ & $\begin{array}{l}\text { Mass of particles } \\
\text { retained(g) }\end{array}$ & $\begin{array}{c}\text { \% } \\
\text { Retained }\end{array}$ & $\begin{array}{c}\text { \% } \\
\text { Cumulative } \\
\text { Retained }\end{array}$ & $\begin{array}{l}\text { \% } \\
\text { Cumulative } \\
\text { Passing }\end{array}$ \\
2 & $2.00-4.00$ & 1.0 & 0.7 & 0.7 & 99.3 \\
1 & $1.00-2.00$ & 5.1 & 3.5 & 4.2 & 95.8 \\
0.425 & $0.425-1.00$ & 53.5 & 37.0 & 41.2 & 58.8 \\
0.250 & $0.250-0.425$ & 29.5 & 20.4 & 61.6 & 38.4 \\
0.150 & $0.150-0.250$ & 20.9 & 14.5 & 76.1 & 23.9 \\
0.063 & $0.063-0.150$ & 30.3 & 21.0 & 97.1 & 2.9 \\
PAN & $0.000-0.063$ & 4.3 & - & - & - \\
\hline
\end{tabular}

Key: PAN is the last carrier in the set of sieves

$$
\begin{aligned}
& \mathrm{C}_{\mathrm{UA}}=\frac{D_{60}}{D_{10}}=\frac{0.333}{0.073}=4.562 \\
& \mathrm{C}_{\mathrm{CA}}=\frac{D_{30}^{2}}{D_{10} * D_{60}}=\frac{0.145^{2}}{0.073 * 0.333}=0.865 \\
& \mathrm{C}_{\mathrm{UB}}=\frac{D_{60}}{D_{10}}=\frac{0.430}{0.086}=5.000 \\
& \mathrm{C}_{\mathrm{CB}}=\frac{D_{30}^{2}}{D_{10} * D_{60}}=\frac{0.186^{2}}{0.086 * 0.430}=0.936
\end{aligned}
$$

\begin{tabular}{|c|c|c|c|c|c|c|c|}
\hline S/No. & PARAMETERS & UNITS & RAW WATER & \multicolumn{4}{|c|}{ TREATED WATER SAMPLES (TIME) } \\
\hline & & & SAMPLE & 10MINS & 20MINS & 30MINS & 40MINS \\
\hline 1 & $\mathrm{PH}$ & - & 10.2 & 8.9 & 8.6 & 8.1 & 7.8 \\
\hline 2 & Colour & - & BROWN & CLEAR & CLEAR & VERY CLEAR & VERY CLEAR \\
\hline 3 & Turbidity & FAU & 41 & 9 & 6 & 3 & 1 \\
\hline 4 & Temperature & ${ }^{\circ} \mathrm{C}$ & 30.3 & 29.7 & 29 & 27.8 & 26.2 \\
\hline 5 & Conductivity & $\mu \mathrm{s} / \mathrm{cm}$ & 342 & 176 & 164 & 158 & 144 \\
\hline 6 & TSS & $\mathrm{mg} / \mathrm{l}$ & 0.287 & 0.12 & 0.088 & 0.076 & 0.041 \\
\hline 7 & TDS & $\mathrm{mg} / \mathrm{l}$ & 641 & 567 & 532 & 493 & 487 \\
\hline 8 & TS & $\mathrm{mg} / \mathrm{l}$ & 641.287 & 567.12 & 532.088 & 493.076 & 487.041 \\
\hline 9 & BOD & $\mathrm{mg} / \mathrm{l}$ & 48 & 22 & 16 & 12 & 10 \\
\hline 10 & COD & $\mathrm{mg} / \mathrm{l}$ & 146 & 46 & 44 & 39 & 37 \\
\hline 11 & DO & $\mathrm{mg} / \mathrm{l}$ & 1.8 & 3.2 & 3.8 & 4.03 & 4.98 \\
\hline 12 & Nitrate & $\mathrm{mg} / \mathrm{l}$ & 5.12 & 1.15 & 1.08 & 1.03 & 0.97 \\
\hline 13 & Phosphate & $\mathrm{mg} / \mathrm{l}$ & 0.066 & 0.013 & 0.005 & 0.0012 & 0 \\
\hline 14 & Sulphate & $\mathrm{mg} / \mathrm{l}$ & 116.42 & 32 & 28 & 24 & 22 \\
\hline
\end{tabular}

TABLE 4: Optimum Dosage of Activated Carbon Sample using COD

\begin{tabular}{|lcccc|}
\hline S/No. & Mass of sample $(\mathbf{g})$ & $\begin{array}{c}\text { Volume of } \\
\text { sample used }\end{array}$ & COD (mg/l) & $\begin{array}{c}\text { \% reduction of } \\
\text { COD }\end{array}$ \\
1 & RAW & 100 & 146 & - \\
2 & 20 & 100 & 58 & 60 \\
3 & 30 & 100 & 49 & 66 \\
4 & 40 & 100 & 44 & 70 \\
5 & 50 & 100 & 47 & 68 \\
\hline
\end{tabular}

TABLE 5: Results of Wastewater Analysis after Treating with Optimum Dosage 
From Table 1, it is seen that the surface area for sample A was $2567.32 \mathrm{~m}^{2}$ and that of sample B was $2987.69 \mathrm{~m}^{2}$, indicating a higher surface area for sample B, and also porosity which is an extent of the surface area was $48 \%$ and $72 \%$ for sample $\mathrm{A}$ and $\mathrm{B}$ respectively. This increase in the surface area and porosity of sample B is as a result of impregnation with $\mathrm{H}_{3} \mathrm{PO}_{4}$ which increases the heat energy on the pyrolysis process, and thus initiate to develop the porosity of activated carbon [11]. These results obtained is an indication that the samples follow the direct proportionality trend between porosity and surface area and that sample B is better in terms of these characteristics

Organic content which is also the ash content of a sample is $12.57 \%$ and $7.3 \%$ for sample A and B respectively. This shows that sample B has a higher yield than that of sample A, since ash content is not a desired parameter in an active carbon sample. Moisture contents were $0.32 \%$ and $0.27 \%$ for sample A and B respectively; although both are comparatively small due to the cooling in desiccators after pyrolysis, sample B exhibited a lower value, making it the better sample for this feature. The $\mathrm{pH}$ value of sample $\mathrm{A}$ in solution was 8.76, which shows that its solution is alkaline, which may be as a result of the presence of Calcium carbonate and protein as some of the compositions of the shell [12]; while that of sample B was 7.04 which is as a result of the treatment with an acid and further washing to approximately a neutral $\mathrm{pH}$ in the preparation process. Other parameters are bulk density and specific gravity which are $1.485 \mathrm{~g} / \mathrm{cm}^{3}$ and 2.62 for sample A, while that recorded for sample B is $1.061 \mathrm{~g} / \mathrm{cm}^{3}$ for bulk density and 2.50 for specific gravity. Bulk density is an important parameter when carbon is removed by filtration because it determines how many pounds of carbons can be contained in a filter of a given solid capacity and how much treated liquid is retained by the filter cake. Carbons with adequate density also help to improve the filtration rate by forming an even cake on the filter surface. The American Water Work Association has set a lower limit on bulk density at $0.25 \mathrm{gm} / \mathrm{ml}$ for Granular Activated Carbon (GACs) to be of practical use . The bulk density of prepared samples in this work is within that limit as stated above.

From Tables 2 and 3, it is seen that the range of particle sizes most predominant in the samples were $0.425 \mathrm{~mm}-1.00 \mathrm{~mm}$ and those in the range of $0.063 \mathrm{~mm}-0.150 \mathrm{~mm}$. The former shows a coherence with the sieve diameter, $600 \mu \mathrm{m}(0.6 \mathrm{~mm})$ used in the process and the latter is mostly as a result of impact used as the technique for crushing the snail shells, which is a single acting force in a particular direction. Furthermore, the values obtained for $\mathrm{C}_{\mathrm{c}}$ and $\mathrm{C}_{\mathrm{u}}$ as obtained below gives an indication on the uniformity of the particle sizes and the quality of grading done in the crushing process. Where $\mathrm{D}_{10}$ is the size such that $10 \%$ of the particles are smaller than the size, and $\mathrm{D}_{30}$ and $\mathrm{D}_{60}$ are similarly defined for $30 \%$ and $60 \%$ respectively; where $\mathrm{D}_{10}$ is known as the effective size because it controls the water flow in a sample. Usually, as the distribution curve straightens out, the range of sizes in the carbon sample is wide and the sample is considered un-uniform; a steeper curve characterizes a narrow range of particle, i.e. a uniform soil. As the coefficient of uniformity is higher, the range of particle sizes are larger, and the and the sample is more un-uniform. Usually, particle samples considered as uniform are those whose coefficient of uniformity is less than 4 . Also, $C_{c}$ is used to describe the general shape of the distribution curve where the significance of diameter is same presented for $\mathrm{C}_{\mathrm{u}}$. For a well-graded sample, the coefficient of curvature is comprised between 1 and 3; for values out of this range, the particle sample can be considered as poorly graded

From Table 4, it is seen that the optimum dosage of the activated carbon for treating the waste water sample was $40 \mathrm{~g}$ against $100 \mathrm{ml}$ of water, because it gave the best result in the COD analysis. Although this is not a general standard for water treatment as different setup can be used, but it was adopted for the purpose of this experiment and yielded results. Also, change in the physicochemical parameters as the raw waste water was treated with varying time is given in Table 5 . The results show that there is actually an improvement of these physicochemical parameters with time, comparing the raw wastewater sample and the treated samples that varied with time. Parameters were best at $40 \mathrm{mins}$ followed by that of $30 \mathrm{mins}$, 20mins, and $10 \mathrm{mins}$ in decreasing order. Also from the result, it is seen that almost all the parameters observed a decrease except for DO, which had an increasing trend. The observed trends for all the parameters are accurate in terms of water treatment and improvement of water quality.

More specifically, it is seen that the $\mathrm{pH}$ for the raw water sample was very high, this is due to the use of caustic in the washing operations in the beverage company where the wastewater was obtained; this also may have contributed to its high temperature. Treating with the activated carbon sample of relatively less $\mathrm{pH}$ helped in annulling the very high alkalinity of the waste water over time.

The low value of dissolved oxygen and high values of BOD and COD for the raw waste water show that there is a high competition for the DO by the suspended, dissolved substances and micro organism in the wastewater, this is an indication of pollution. Thereafter, there was an increase in the value of dissolved oxygen and decrease in Biochemical and chemical oxygen demand after treatment, indicating an improved quality of the wastewater. The quality of any water is high when there is increase in dissolved oxygen (DO) and decrease in Biochemical oxygen demand (BOD) after treatment. This improved quality of the water sample after treatment indicates the effectiveness of the treatment. 
The high values of conductivity and turbidity of the raw wastewater sample is an indication that it contains high amount of dissolved and suspended particles and ions, these were seen in the values of TSS and TDS. The drop in their values with time as shown in table 5 also indicates the effectiveness of the activated carbon sample used. Phosphate, nitrate and sulphate are all unwanted ions which impede on the conditions of the wastewater over time, especially in the ecosystem of their final discharge point. Nitrate ion in water can cause methaemoglobinamea in infants, the high amount of sulphate gives the wastewater an offensive odor, the concentration of phosphate present in the raw wastewater sample can cause algae growth and eutrophication when discharged into the environment and water bodies (rivers), this indicate strong pollution and therefore calls for treatment before disposal [13]. The drop in the values of these parameters after treatment with time, also indicates an appropriate treating procedure and the effectiveness of the activated carbon sample.

\section{CONCLUSION}

The results of this study showed that it is feasible to prepare activated carbons with relatively high surface areas and porosity from snail shells by direct and controlled carbonization, although activation with $\mathrm{H}_{3} \mathrm{PO}_{4}$ produced activated carbon with better developed porosity and less ash content.

This snail shells are good coagulants, effective in the treatment of waste water at any $\mathrm{pH}$, and therefore has the potential for use in treating waste water from other industries.

\section{REFERENCES}

[1] Aluyor, E.O. and Badmus, O.A.M. (2008): "COD Removal from Industrial Waste Water using Activated Carbon prepared from Animal horns”, African J of Biotech, Vol.7, pp 3887-3891.

[2] Vedula (2011): Flexible Nano-feeds of Carbide-derived Carbon

[3] Michal K, Bruno, D and Ewa C.B (2005); J.Phys. Chem. B. 109, 9216-9225

[4] An-Hui Ru and Jing-Tang Zheng (2001): Journal of Colloid and Interface Science, 236, 369-

[5] Junichi Hayashi, Atsuo Kazehaya, Katsuhiko Muroyama, Paul Watkinson A. (2000): Carbon 28, 1873-1

[6] Viswanathan, B., Indra Neel P., \& Varadarajan, T.K. (2009): "Methods of Activation and Specific Applications of Carbon Materials", National Centre for Catalyst Research, Indian Institute of Technology, Madras, Chennai 600 (036

[7] Asia, I.O. and Akpohonor, E.E. (2007): "Characterization and Physicochemical Treatment of Waste Water from Rubber Processing Industry”, International Journal of Physical Science, Vol.2(3), pp 061067.

[8] Hu, Z. and Srinivasam, M.P. (1999): "Preparation of High- Surface Area Activated Carbons From Coconut Shells", Microporous and Mesoporous Materials, Vol.27, no.1, pp 11-18(8).

[9] Ademoroti, C.M.A. (1996a): Standard Methods for Water and Effluent Analysis, Foludex Press Ltd, Ibadan, Nigeria

[10] APHA (1998): "Revisions to Standard Methods for the Examination of Water and Waste Water (supplement)", America Public Health Association, Washington D.

[11] Mun, S.P. and Seo, G. (2004): "Preparation of Activated Carbon from Pinus Desiflora Bark by $\mathrm{ZnCl}$ Activation. J. ind. Eng. Chem., 10(5), 728-732.

[12] Aboua, F. (1995): "Proximate Analysis and Mineral Content of two Giant African Snail consumed in Ivory-Coast", Tropical Science England. Pp 220-222.

[13] Brighetta, A. (2010): Nanofiltration for Water and Waste Water Treatment-a Mini Review, Drinking Water Engineering and Science(DWES), Copernicus, Gottingen, Germany.

[14] Ganan J., Gonzalez J. F., Gonzalez-Garcia C. M., Ramiro A., Sabio E., Roman S. (2006): Applied Surface Science, 252, 59 